IJ§ER

ISSN: 2149-5939
International Journal of Social Sciences and Education Research

Online, http://dergipark.gov.tr/ijsser

Volume: 2(2), 2016

\title{
Statements from teacher training-starts of one's career: A teaching orbit
}

\author{
Béla Molnár ${ }^{1}$
}

Received Date: 02 / 12 / 2015

Accepted Date: 29/ $01 / 2016$

\begin{abstract}
The pensioned-off teachers of primary school made up their mind in the period of one and a half decades after the world war to go on for higher education at a training college of primary school teachers. Interviewing a diminishing number of eye-witnesses about the process of their becoming a primary school teacher is a pressing task of our current research into educational history which is not to be delayed. From among the basic kinds of interview we applied a structural interview in order to explore the motives of the choice of profession, the attitude towards the training institute of primary school teachers, the opinions about the training. On the grounds of the interviews we present the attitudes and experiences of those graduating at an institute training primary school teachers in a rather qualitative approach. During the analysis of the interviews the hypothesis was confirmed that one-time students already chose a profession with sense of vocation at the time of their choosing a career. They told about their teachers that they had taught and educated with committed professional expertise. The professional work of the institutes training primary school teachers was considered to be successful by every interviewed person without exception. The strength of the one-time school type was thought to be the unity of theory and practice, the successfulness of practical training and the stressed methodical training. In the remembrance of all those interviewed there was a positive picture about the institutes training primary school teachers.
\end{abstract}

Keywords: History of education, Training college of primary school teachers, Hungary

\section{Introduction}

The pensioned-off teachers of primary school - age group of 70 or 80-year-old persons - made up their mind in the period of one and a half decades after the world war to go on for higher education at a training college of primary school teachers. Interviewing a diminishing number of eye-witnesses about the process of their becoming a primary school teacher is a pressing task of our current research into educational history which is not to be delayed.

The objectives of the research can be given as follows:

- By means of interviewing: the verification of the fact that the students of the institute received a suitable preparation during the 4 years of the training for primary school teachers.

Basing on the national specialized literature in educational history, the hypotheses of the current research were as follows:

1. Professional values kept on functioning guaranteeing the successfulness of training.

2. The content and amount of the subjects in the training at secondary level made it possible to acquire the basic knowledge, expertise and skills, which ensured the successfulness of the effective work for primary school teachers.

\footnotetext{
${ }^{1}$ Head of institute, College Assoc. Prof., PhD, University of West Hungary, Berzsenyi Dániel Teacher Training College, SZOMBATHELY/HUNGARY mbela@mnsk.nyme.hu
} 
Molnár, B. (2016). Statements from teacher training-starts of one's career: A teaching orbit. International

Journal of Social Sciences and Education Research, 2 (2), 410-418.

From among the basic kinds of interview we applied a structural interview in order to explore the motives of the choice of profession, the attitude towards the training institute of primary school teachers, the opinions about the training. The sample comprised 178 persons. The sample offers a good representation about those graduated at a training institute of primary school teachers at a secondary level on the grounds of their social background and their going on for higher education. The questions of the interview were open questions in order that those interviewed could formulate their own opinion. Among the open questions there are items requiring both short and long explanation.

\section{The history of training primary school teachers at secondary level from 1945 until its becoming of high level}

The study presents the history of the intermediate teachers' training schools working in Hungary in the middle of the 20th century. The aim of the short paper is to write about the fast and perplexing changes in the structure of the Hungarian teachers' training which took place only in 15 years. 'The aftermath of the consecutive alterations was that our teacher training system relapsed onto the 4-year intermediate level that developed in our country as early as 1881 . This fact also proves that despite all kind of any 'good intentions', you cannot always refer to improvement, sometimes the fact of stagnation or regression must be stated also.' (Dráviczki, 2002, 29)

In 1944/45, the work of the Ministry of Public Education guiding education, the functioning of regional superintendence of schools, existence of denominational schools in the Hungarian school system all meant continuity. There was a continuity, too, in the training of teachers of primary schools. The dual structure of five years created in 1941 survived, in this system the students of the third year of a lycée could go on for higher education at the 4th then the 5th year of a training institute of primary school teachers. In November 1947, two pedagogical colleges began to function in Budapest and Szeged where class teachers were trained for primary schools and so were trained specialized teachers for teaching certain groups of subjects at the senior section of primary school. Training time comprised 6 semesters at the college. In 1948 ecclesiastical schools were nationalized then the Minister stopped the training of primary school teachers at secondary level. Pedagogical colleges functioned on the grounds of their original objectives until 1949 then the training of primary school teachers was made a task of colleges.

A comprehensive form of secondary schools took place in Hungary in 1949. It settled the situation of educational institutes of secondary schools in the system of education as well as the relation between the aims of professional training and general education. A system of general and specialized secondary grammar schools was built up. Pedagogical secondary grammar school became a formation that lasted four years adapting itself to the system of secondary schools.

From 1949, the training period' was reduced to four years, respectively reaching the five years only with the practice year spent in an outer school - which five years meant only the minimum program even at the end of the last century and was effectively carried through in 1923 (Kelemen, 1999: 57). In the system of the curricular aims of the teachers' training institutes, outstanding roles were given to elements, e.g. 'to spot profoundly the progressive pedagogical traditions and the top-ranking Soviet pedagogy' or 'to educate conscious socialist teachers who love their profession' (Gombos, 2011, 71). 
Molnár, B. (2016). Statements from teacher training-starts of one's career: A teaching orbit. International Journal of Social Sciences and Education Research, 2 (2), 410-418.

In 1950 a decree with legal force created institutes of training primary school teachers. It was the task of the institutes training primary school teachers to offer theoretical and practical formation for educators who are suitably qualified for the junior section (1st to 4th classes) of primary school and who are generally educated capable of going on for higher studies. After attending the institutes of training primary school teachers, students sat for a final exam. After the final exam, they were employed in schools as paid practising primary school teachers for a year. At the end oif the probationary year training was accomplished by sitting for a successful qualifying exam for primary school teachers.

In the 'intermediate teachers' training schools, preparation for the complex role of a primaryschool teacher' was the task of the students being educated there.' Improving the students' multisided personal development was implemented with an exceedingly lavish system of activities and - let us use a modern word - with vivid extracurricular programs, whilst keeping track of making the students acquire the necessary theoretical information (Vincze, 2014, 96).

Between 1945-1959, ' in the period being very much complex in itself and to be divided into some more periods, the primary-school teachers made efforts to insist on teaching writing-reading-counting, that is to meet in all circumstances their basic commitments towards the school pupils and parents. That is why, we may well say that in that period the most important specific feature from the point of view of the primary-school teachers was to be engaged in the observance of the nation.' (Mikonya, 2014, 43)

\section{Interpretation of the results of interviews}

On the grounds of the interviews, the attitudes and experiences of those having a degree of teachers' training secondary school will be rather shown by means of a qualitative approach. The eyewitnesses interviewed who remembered their secondary school years evoked the weekdays spent at the teachers' training school by putting the topic in a micro-historical framework (Seidman, 2002).

The qualification of those involved in the conversations points to the fact that every fourth person having the degree of teachers' training secondary school went on for higher education. $19,1 \%$ of them obtained a degree at a college, and 3,5\% of them got a university degree. Those having college or university degrees primarily obtained qualifications for primary or secondary schools or even a special qualification for educating children with handicap. Going on for higher education and obtaining further degrees in teacher training are characteristics for both the sample and the population alike. Those interviewed come from working class, employee or peasant families. One in five interviewees has intellectual background.

\subsection{Choice of profession}

To investigate the motives of the choice of profession, we established a system of categories whose frequency order is as follows:

1. "I like children. I would like to deal with small children."

2. “Her/His teacher's positive impact, encouragement. “

3. "She/He had a sense of vocation (She/He could not imagine her/his life in another way. She/He has always wanted to be a teacher.) “

4. "Because of family traditions, example of teaching parents, relatives. " 
Molnár, B. (2016). Statements from teacher training-starts of one's career: A teaching orbit. International

Journal of Social Sciences and Education Research, 2 (2), 410-418.

5. "She/He helps others. "

6. "It is good, nice to teach. "

There were few interviewees who indicated the motive of their choice of profession in the fact that

- They wanted to have early, safe self-supporting salary,

- They expected teaching career to be a safe future providing advance,

- They were the ones who could accomplish their parents' wishes

- Teachers' training schools offered qualification, secondary grammar schools only offered a certificate of final examinations,

- They liked learning, reading,

- They did it because of going on for higher education.

The choice of career happened out of necessity in few cases; there was one person who indicated the motive that it was not him who had chosen but the County School Committee head directed him to the teachers' training school. There were some practical reasons as well: the school was nearby, it was an ideal profession for girls.

Among the motives of choosing teaching career as a profession, there are humanistic reasons (love of children, helping others) in the first place. The whole-hearted affection towards children creates the basis of loving one's profession forming gradually then that of sense of vacation becoming consolidated later on (Hegedüs T., 1997, 240).

The choice of profession of those interviewed was determined, influenced by the surroundings of the interviewees' primary schools and their family traditions. In the 1950s, students were accepted at the teachers' training school by having chosen teaching career as their mission in life. The love of children the love for profession and highly responsible pedagogical work are all worded in most answers, their summary is shown in the following passage: "The thing I answer to it at once is that I very much like children, it is a pleasure for me to experience the children's affection and love. There is no better feeling when I can see that I am important for my students and they like me. It is not a simple profession but a vocation which offers me much pleasure. The second thing I usually answer to this question: it is a very interesting profession, a great challenge. It is a very variegated activity seeing that every child is somehow different. The third thing I can answer: my teachers made a positive impact on me, many of them were worth an example. It is a kind of work full of responsibility. I like being with other people, I have always liked community."

Experiencing the teacher's role from one's childhood also appeared in the conversations, the example of parents and relatives working as teachers was also a determining factor. "I used to lead a day-care centre every summer. I taught reading in the junior class of my mother several times thus I could make myself acquainted with the tricks of teaching pretty soon." There was also another conversation touching on the inclining effects of family traditions: "My father is a teacher, my grandfather is a teacher, and my father's brothers were also teachers. Well, I was born to do this."

The few persons, who chose teachers' training college out of necessity, all stated that they had taken a liking to their school and later to their profession. 
Molnár, B. (2016). Statements from teacher training-starts of one's career: A teaching orbit. International Journal of Social Sciences and Education Research, 2 (2), 410-418.

\subsection{Aptitude test}

The aptitude test embraced several areas between 1945 and 1959. In the 1940s, the entrance examination was more complex: "As for outward appearance, they examined whether I was healthy. We did some simple gymnastic exercises then we were led to a large room where there were a lot of children playing. On the edge of the room, nuns were watching how well we succeeded in establishing contact with the children. In a short time, I began to play with them. In the end, we were informed about who had sense for dealing with children, whom they suggested to take up or abandon this career."

For a short period of time, no aptitude tests were carried out thus the ill-suited were directed to other schools in the first class. From 1952, the applicants' musical capacities were gauged at the chief town of the districts.

In the 1950s, it was not only musical aptitude which was considered as decisive factor at entrance examinations - good primary school achievement became more and more important. In the case of the last classes receiving secondary education, candidates already experienced a wideranging assessment: "The entrance examination of the four-year training school was pretty hard as they only accepted as few as one class. Everybody started by taking an entrance examination in music and it was crucial as the ones who were not up to the scratch, were warned off. Afterwards, there were written examinations in mathematics and Hungarian. Finally, we took an exam in Hungarian."

\subsection{Studies at secondary school}

Those interviewed did not worded their ideas or expectations concerning their training because of their adolescent choice of career. The order of the preferred subjects was as follows: Hungarian, Music, Mathematics, History, Pedagogy, Geography, Psychology, Physical Education, Biology, Arts, Methodology, Chemistry, Practice Teaching, Logic, Physics, Russian, Manual Training. The subjects of general education were the most popular ones. Among professional subjects, Pedagogy got the fifth place. Psychology was considered to be harder than Pedagogy. It is surprising that Teaching Practice fell into the background. The least preferred professional subject was Logic. Physics, Chemistry and Russian can be named as disliked subjects.

As far as teachers working at teachers' training colleges are concerned, those remembering emphasized personal exemplification, professional expertise. Teachers were described with the following characteristics: "They were outstandingly prepared. There were many of them who mainly tried to hand down civil values to students. They were authorities on their special subjects, their personal example meant a lot for us. Morally, they set us irreproachable examples. Professionally, they were self-confident and of great knowledge."

Each interviewee stated that theory and practice were built one upon the other in secondary education.

The question concerning the level of general knowledge offered by the training school divided the interviewees into several groups which are as follows:

1. "Secondary grammar school provided knowledge of higher level." "The curriculum of training school only deferred from that of secondary grammar schools in view of pedagogical subjects. The subjects providing general training thoroughly established the basis of general knowledge seeing that teachers strictly demanded learning." 
Molnár, B. (2016). Statements from teacher training-starts of one's career: A teaching orbit. International Journal of Social Sciences and Education Research, 2 (2), 410-418.

2. "Those studying at teacher training schools were at a higher level." "Their knowledge was wide-ranging; it can also be seen on the grounds of the high number of subjects."

3. "They got knowledge at intermediate level. By and large, they were at the same level as students of secondary grammar schools." "Those studying at teachers' training schools were rather at the level of secondary schools with a specialization in the sciences."

4. "Considering the epoch, they (those studying at teachers' training schools) were thought to be qualified experts with general knowledge." "We got general knowledge at basic level and it was enough to develop it." "Secondary grammar schools focussed on education and concentrated on theory. Teachers' training school prepared for practical and independent public life." "In comparison with secondary grammar schools, it was less but it was pretty suitable for the profession."

Those remembering considered all the forms of practical training as very important. In the course of practical teaching, teachers of demonstration schools and the teachers of Pedagogy judged the teaching of the trainees in a helpful way. Trainee teachers had 12-20 lessons at demonstration schools.

\subsection{Probationary year}

From 1950 onwards, the training was qualified as lasting for five years according to the official documents seeing that a probationary year was inserted in the period after the final exams. The document entitled 'Regulation of Teacher Trainees' Probationary Year' was published in 1951. It contained rules concerning the teacher trainees' work and it also appointed those responsible for organising and checking the practice. The aim and task of the probationary year was defined by Komlósi Sándor as follows: 'The probationary year had a dual aim that was also defined by law. On the one hand, it was to deepen the career-starter educators' knowledge and skills acquired at teachers' training colleges or university colleges in relationship with teaching at primary schools and participating in real teaching- On the other hand, however, it was also meant as a kind of preparation for the exam, the accomplishment of their studies. All primary school headmasters, educators, all the employees of the educational administration had to consider them as educators who were not yet fully prepared. They were to be helped to develop their theoretical knowledge to conscious and right practice in education and teaching, prepare for their state exam well, and finally the sense of vocation that was still awakening in many young people should become stronger.' (Komlósi, 1954, 3)

Those interviewed spent the probationary year at their dwelling place (7\%), near their place of residence (64\%), in remote settlements $(26 \%)$ and in Budapest $(1 \%)$. Trainees were generally assigned to villages, farming centres and farmsteads lying far away from their dwelling places thus they lived in lodgings.

Trainee teachers generally taught in classes drawn together. Contrary to rules, they also got assignments to teach subjects in the senior section of primary school. They had several out-ofschool activities, they caries out agit-prop work and activities in connection with the movement:

- Organisation of the cultural life in the village (leading the library, dance groups, stage-plays, sewing and other courses),

- Arrangement of community celebrations,

- Teaching in evening schools and illiterate courses, 
Molnár, B. (2016). Statements from teacher training-starts of one's career: A teaching orbit. International Journal of Social Sciences and Education Research, 2 (2), 410-418.

- Assistance in organising co-operative farms, population census, stock-taking of animals, harvest, produce collection,

- Subscription to Peace Loans, supervision in cultural centres while watching the television collectively.

Professional assistance was, in many cases, only a nominal matter. The main protector of the trainee teacher was the older teacher. The interviewees also indicated the headmaster as a helper. $17 \%$ of those interviewed remained without help during their probationary year, only $8 \%$ of them were satisfied with the help provided by the mentor, leading teacher. $45 \%$ of the trainee teachers had no contact with the mother school, they were left alone. It mainly occurred in the cases of those whose training school had been winded up. $16 \%$ of the interviewees reported good contact, in case of a problem they went to the training school or sent a letter, every quarter of a year they appeared in the training schools to have a consultation.

Let a quotation stand here about an exemplary probationary year: "As a trainee teacher in the probationary year, I was assisted by a teacher who constantly participated in my lessons, reviewed my lesson plans, as a matter of course, he also took part in the lessons, and we always talked over what I had done right and wrong, what I should have been done in another way. Of course, I had also prepared for these lessons by using every kind of resources, reference books and the like. Every quarter of a year we went to Esztergom to participate in consultations. We spent there three days, during this period all the notes were inspected that had been given to us by the instructor who had taken part in our lessons... In the course of the qualifying examination, we had to present all the things that we had practically done in the given year."

The practice was controlled by the headmaster, the deputy headmaster, the school inspector of the primary school. The headmasters, educational leaders, subject teachers of the teachers' training schools could rarely go to carry out inspections.

When assessing the probationary year, we have to mention as a positive feature that trainees could practise in the teaching process for a long time, in the meantime their work was supported. It could have had a real value if teacher trainees had not been left alone for this academic year, they should have been in daily contact with the training institute. In the course of the probationary year, the theoretical knowledge of the trainees may also have decreased that is why it would have been more expedient to organise the written and the oral part of the qualifying exam simultaneously with the final exam. Probationary year can be considered as the organic part of teachers' training, it functioned as an uninterrupted individual complex practice of profession. In implicit form, it also reduced the lack of primary school teachers. In the form, it was realised it only had an insignificant professional value.

\subsection{Judging the level of training}

The merits, strengths of the training can be summarised in the categories to be mentioned here:

- Pedagogically speaking, it gave a good preparation. "It prepared me pedagogically well."

- Those studying at the teachers' training school received an outstanding practical training. "There was much practice."

- There was much emphasis on methodological training. "They gave us a lot of practical, methodological techniques; they prepared us how to teach children." 
Molnár, B. (2016). Statements from teacher training-starts of one's career: A teaching orbit. International Journal of Social Sciences and Education Research, 2 (2), 410-418.

-They received famous preparation. It was poor in knowledge but demanding in methodological aspect."

- This type of school had a wide range of activity offer. "Education was varied and colourful."

- The education of the age group 14-18 years became evident. "It trained students for becoming nice people, doing hones work, having sense of duty and being reliable."

- Human behaviour was strongly influenced, shaped. They gave personal care to every student."

Those being satisfied with the training could not name any deficiencies. Graduates all spoke about being satisfied.

\subsection{Judging the career}

Each of the interviewed thought the choice of career proper, nobody was sorry for having taken teaching career. The majority of the interviewees would decide in the same way, or rather they would only decide like this in case the form of living and existence could come back because they would not make the same decision under present-day conditions. They recommended the teaching career to their children, grandchildren; there are some who follow the example. Because of the changes if time, the minority formulated here as well that they would not recommend the teaching career to their acquaintances.

\section{Summary}

On the grounds of the interviews we present the attitudes and experiences of those graduating at an institute training primary school teachers in a rather qualitative approach. During the analysis of the interviews the hypothesis was confirmed that one-time students already chose a profession with sense of vocation at the time of their choosing a career. They told about their teachers that they had taught and educated with committed professional expertise. The professional work of the institutes training primary school teachers was considered to be successful by every interviewed person without exception. The strength of the one-time school type was thought to be the unity of theory and practice, the successfulness of practical training and the stressed methodical training. In the remembrance of all those interviewed there was a positive picture about the institutes training primary school teachers. The content and the amount of the subjects of the training at secondary level made it possible to acquire general education and craftsmanship. The traditions of training primary school teachers at secondary level were working between 1945 and 1959. Among them we can find the practical acquisition of pedagogical techniques, the formation and the development of the sense of vocation of the would-be primary school teachers.

\section{References}

Dráviczki, S. (2002). A pedagógus. Bessenyei György Könyvkiadó, Nyíregyháza

Gombos, N. (2011). A közép- és a felsőfokú tanítóképzés fejlődése Magyarországon - a korabeli tantervek tükrében. SZIE Gazdaság és Társadalomtudományi Kar Tanárképző Intézet, Gödöllő

Hegedűs, T. A. (1997). Pszichológia. Fejlödés, nevelés, szocializáció, pedagógusok. Aula Kiadó, Budapest

Kelemen, E. (1999). Gondolatok a magyar tanítóképzés kettős évfordulóján. In: Donáth, P., Hangay, Z.

(Eds.). Filozófia - Müvelődéstörténet. Trezor Kiadó, Budapest, pp. 53-63.

Komlósi, S. (1954). Neveljünk jó pedagógusokat a gyakorlóévesekből. Nevelők Lapja, Vol. 10. No. 16. 
Molnár, B. (2016). Statements from teacher training-starts of one's career: A teaching orbit. International Journal of Social Sciences and Education Research, 2 (2), 410-418.

Mikonya, Gy. (2014). Hagyomány és modernitás: néptanítói modellek és a jelen kor kihívásai a tanítóképzésben. In Jenei Teréz (Ed.): Hagyomány és modernség a XXI. századi tanítóképzésben. Nyíregyházi Főiskola, Nyíregyháza, pp. 31-56.

Seidman, I. (2002). Az interjú mint kvalitatív kutatási módszer. Müszaki Könyvkiadó, Budapest 